\title{
NOTA PARA UNA CIERTA POESÍA LATINOAMERICANA ACTUAL
}

\author{
José Kozer \\ josekozer@comcast.net
}

El ANACOLUTO reemplaza en el Neobarroco, como estrategia retórica, a la METONIMIA. Hasta hace poco la poesía se centraba en la metonimia, buena parte de la poesía latinoamericana del siglo XX participa de esta condición, se centra en dicho recurso estilístico.

La más actual poesía latinoamericana, en particular la que hace del discurso una densidad, una proliferación, como es el caso del llamado Neobarroco, privilegia la figura retóricadel ANACOLUTO.

La metonimia se basa en la sustitución: esto por aquello, la parte por el todo; en el caso de la metáfora, en el intercambio (de comparando y comparado) que conduce a la transformación.

Este sistema de expresión, en nuestro momento histórico (el devorador de la tecnología), dada la complejidad material de la vida, con sus cambios y bruscas, aceleradas alteraciones, se vuelve insuficiente.

Los poetas del momento se ven obligados a recurrir al anacoluto, que con su continuo DESLIZARSE, y su función base de DESPLAZAMIENTO, abarca más y mejor la compleja realidad histórica que vivimos. Este ABARCAR DESPLAZANDO signa la poesía más arriesgada y experimental de la lengua castellana, aquélla que tiende a alejarse de lo episódico y conversacional. La poética del ANACOLUTO tiende a lo ABRUPTO, a la BRUSQUEDAD de expresión dentro de lo proliferante: una captación de la rapidez de todo lo actual, actualidad que se vuelve en poco tiempo obsoleta, postergando así de continuo lo inmediato. Abarcar lo inmediato y más allá de lo inmediato, es la función del Neobarroco, vía el recurso estilístico del anacoluto.

El CENTRO desaparece, la TRANSPARENCIA de expresión se difumina y da paso a una cierta oscuridad cercana al misterio original y a la posible hecatombe histórica a la que parecemos abocados. La poesía actual, que suele denominarse poesía neobarroca, del lenguaje o de la dificultad, conforma una jungla lingüística, maraña urbana, con una suciedad y alteración brutal, violenta: de ahí la violentación de la sintaxis. 
En esta práctica poética los caminos se entreveran, se entrecruzan, y al desplazar sus materiales (a veces materiales prístinos, líricos y clásicos, a veces materiales de acarreo, de detrito y basura, una basura que incluye lo excrementicio) acaban por asir irrealidad, por hacer del centro una serie de centros, donde ninguno es privilegiado, donde todos los centros conviven asimétricamente, de modo que la asimetría es el nuevo orden, la nueva armonía.

Prima la DESCENTRALIZACión y es éste el territorio del neobarroco y del anacoluto. Una realidad textual compuesta de bifurcaciones, repliegues: el anacoluto privilegia la sintaxis, que se adapta mejor que otros recursos estilísticos o figuras retóricas (sean de pensamiento, de lenguaje o dicción), al flujo del pensamiento, en cuanto conciencia e inconsciencia y no al rígido esquema de la gramática que el uso impone. Este recurso se pliega mejor al monólogo interior, al flujo de conciencia de larga tradición moderna. Este mecanismo y recurso empieza a volverse normativo, como la novela moderna postjoyceana atestigua, esa novela que en la modernidad arranca con Dujardin, con Gertrude Stein, Virginia Woolf, inter alia.

Es posible que en un futuro no muy lejano tengamos que reaccionar al anacoluto, módulo más que modelo que empieza a desgastarse, y que pone en peligro la siempre viva necesidad de experimentación, la búsqueda de lo desconocido en lo desconocido. Veremos entonces surgir nuevas formas de expresión, formas tal vez nunca recogidas en la retórica más antigua que, se supone, clasificó todo el modo del decir humano de manera exhaustiva. Habrá entonces que crear nuevos nombres, surgirán nuevas etimologías, nuevos páramos de irrealidad.

Una distinción entre el barroco tradicional y el Neobarroco, puede centrarse en la idea de una escritura o, si se prefiere, una literatura, donde impera un cuestionamiento de la tradición (grecolatina, en el contexto de Occidente) desde lo unívoco, de modo que, por ejemplo, un Góngora desbarata mediante la sintaxis, por un lado, y el concepto de divinidad de los dioses paganos, por otro lado, todo un mundo caduco, que ya no rige ni tiene razón seria de ser. Así, Góngora se concentra en el derrumbamiento y ocaso de unos dioses que han perdido su actualidad, su poder. Carecen ya en el siglo XVII de validez. Góngora no se rebela sino que les da un simple papirotazo a unos dioses debilitados, ya apenas existentes, para hacerlos definitivamente caer. Y caen. Caen mediante la retórica de una sintaxis que se repliega, doblega la realidad, la bifurca y amplía, la vuelve proliferante, recurre a la seriedad y al chiste (poesía jocoseria), mas todo ello desde la perspectiva de una realidad, no de dos ni de diez. La referencialidad, por ende, es unívoca, siempre tiene que ver con la tradición grecolatina y con la España barroca enfrentada a esa tradición o, por otra parte, la presencia viva del descubrimiento del Nuevo Mundo. Se trata de desacreditar, de desmitificar (para desenmascarar) una realidad envejecida, trillada, siempre (repito) desde la condición omnímoda y unívoca a la que los poetas del barroco se ven abocados y, de cierto modo, condicionados. Poca 
referencialidad, por ende, poca subtextualidad, poca intertextualidad. Y, por el contrario, mucha DECONSTRUCCIÓN.

En el neobarroco no hay efigie a derrumbar, por el contrario, estamos en un mundo abrumado y abrumador que el escritor neobarroco, desde una densidad y complejidad afín a ese mundo, acoge, referencia y no reverencia, plegándose a la multiplicidad y al simultaneísmo actual (histórico) de una sociedad hecha de rápidos cambios, falsas valoraciones que hay que DESENMASCARAR. Una imagen que puede poner de manifiesto ese modo de operar sería la de un auto que llega, en carretera, a un punto de pago de peaje y tiene once carriles por los que entrar: el auto, en vez de entrar al peaje por un carril, decide entrar, al mismo tiempo, por los once carriles. Esa PROLIFERACIÓN SIMULTÁNEA, visible en la desconcentración ciudadana actual, rige esta densa, ardua, compleja y difícil escritura insaciable, no se da abasto en su variedad y continuas variaciones, ya no mediante las variaciones musicales del Barroco o del Romanticismo, sino de los actuales medios de comunicación, degradadores del lenguaje. 